\title{
Post-Lau Event (late Ludfordian, Silurian) recovery of conodont faunas of Bohemia
}

\author{
LADISLAV SLAVÍK \& PETER CARLS
}

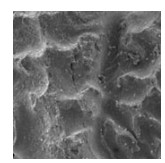

\begin{abstract}
The effects of the Lau Event on conodont faunas in shallow water environments of the Prague Synform were rather moderate in comparison with Gotland. The post-event restoration of conodont diversity following the characteristic post-siluricus faunas with diminished elements and dominated by a long-ranging stock of Delotaxis was gradual and not abrupt. This points to absence of such large gaps in the sedimentation like they had occurred below and had caused the lack of a large upper part of the siluricus Zone. Accordingly, the Bohemian conodont record of diversifying conodont faunas, starting with the entry of "slender spathognathodontids", is comparably complete. Increased diversity and abundance of incoming conodont taxa has enabled a refinement of the regional zonal subdivision. This includes the succession of the plodowskii, latialatus, parasnajdri and crispa conodont biozones for the interval following the Lau Event in the late Ludfordian. The conodont data from Bohemia show that "Oz." snajdri range is largely included in the overlap of Pedavis latialatus and "Ozarkodina" crispa. Accordingly, the use of the problematic stratigraphical unit - the snajdri Interval Zone as a base for the definition of a middle Ludfordian Stage Slice can be misleading. Conspicuous morphological changes in the "Ozarkodina" snadri-“Oz." crispa stocks and in the Ozarkodina typica lineage allow refined inter-regional correlations. - Key words: late Silurian, Ludfordian, post-Lau Event, conodont recovery, Lau Event, Prague Synform.
\end{abstract}

SLAVÍK, L. \& CARLS, P. 2012. Post-Lau Event (late Ludfordian, Silurian) recovery of conodont faunas of Bohemia. Bulletin of Geosciences 87(4), 815-832 (7 figures). Czech Geological Survey, Prague. ISSN 1214-1119. Manuscript received May 30, 2012; accepted in revised form August 20, 2012; published online October 15, 2012; issued October 17, 2012.

Ladislav Slavík (corresponding author), Institute of Geology AS CR, v.v.i., Rozvojová 269, CZ-16500 Praha 6, Czech Republic; slavik@gli.cas.cz・Peter Carls, Institute of Geoecology, Technical University of Braunschweig, Langer Kamp 19, D-38023 Braunschweig, Germany

Numerous studies on Jeppsson's (1998) mid-Ludfordian conodont Lau Event and its effects on conodont faunas and other faunal groups have been presented in recent years (see e.g., Barrick et al. 2010, Manda et al. 2012, Tonarová et al. 2012). A reflection about the influence of the Lau Event on conodont faunas of Bohemia has been provided by Slavík et al. (2010), who interpreted the event as a rather moderate change observed in shallow-water environments and marked by presence of stratigraphic gaps in the vicinities of former volcanic elevations. The present paper refers to the continuation of detailed biostratigraphic studies of the late Silurian strata in the Prague Synform. It focuses on the post-event recovery of conodont faunas during the late Ludfordian.

The precision of global correlation often suffers from incomplete documentation of faunal distribution that is the basis for biostratigraphic framework. Inaccuracies in correlation and spatial image of the interval after the Lau Event on global scale are mostly due to poor biostratigraphic record (partly caused by the corresponding extinction) and/or sedimentological/environmental constraints (e.g., incompleteness of sedimentary record). The lack of "fresh" biostratigraphic data is, however, the major weak point of some recent summarizing studies dealing with early-middle Palaeozoic bioevents and biozonations. The aim of the present paper is to improve the basis for correlation with conodont data from the latest Ludlow of Bohemia and to document the post-Lau Event recovery in conodont faunas. The conodont ranges obtained from sections in the Prague Synform are correlated with data from previous studies in the same region and with corresponding stratigraphic intervals in Gotland, Eastern Baltica, Sardinia and Carnic Alps. This paper is a result of a long-term study focused on the late Silurian conodont stratigraphy in the Prague Synform within the project "Late Silurian integrated stratigraphy".

The first conodont zonation for the late Silurian, developed by Walliser (1964), has been modified subsequently by several authors (for review see Corradini 2009 and Corriga et al. 2009). As regards the latest Ludlow (late Ludfordian), the zones treated in this paper, the siluricus, latialatus and crispa zones, have been changed only 


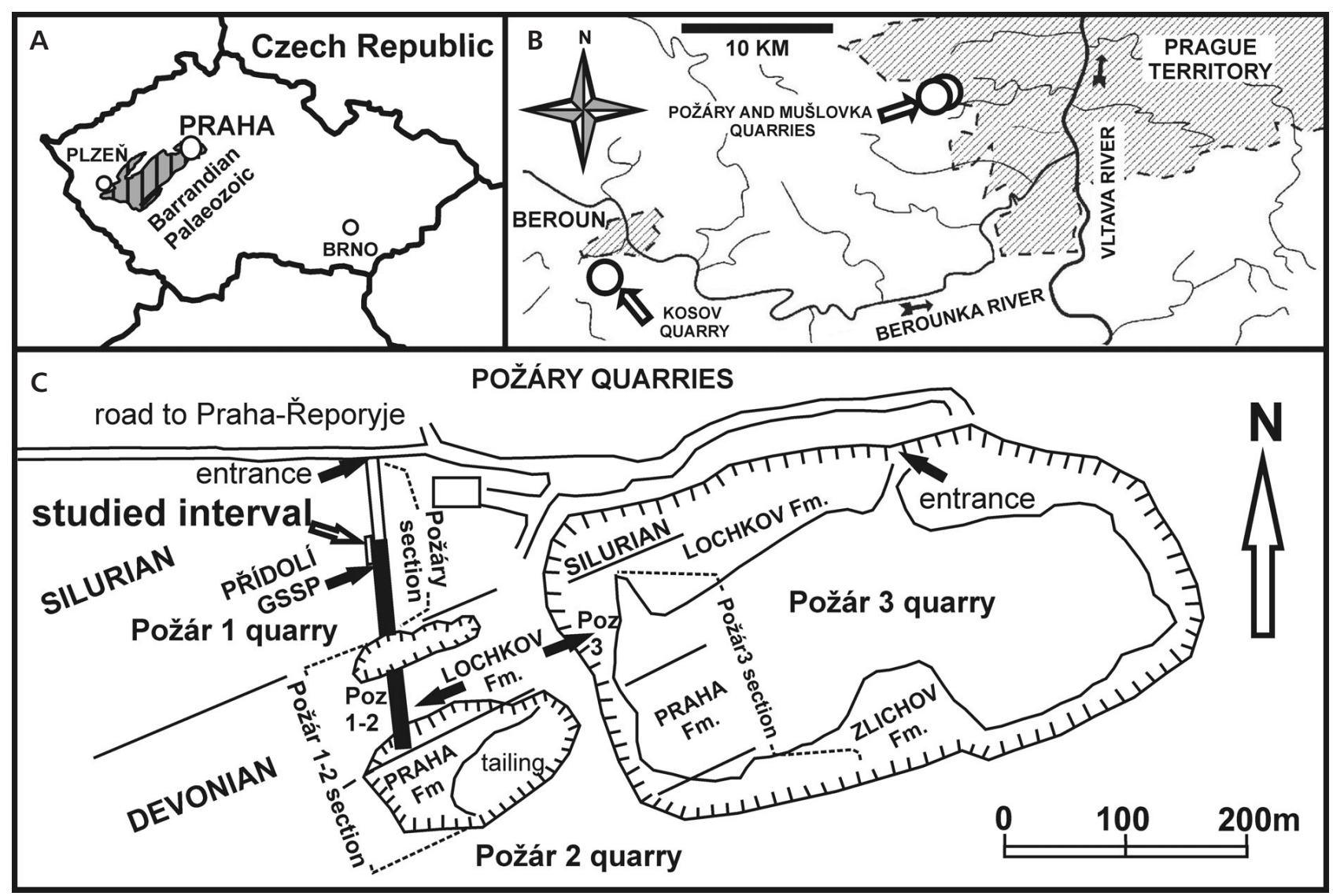

Figure 1. A, B - the position of studied sections within the Barrandian Paleozoic, in the vicinity of Prague. $\bullet$ - detail of the Požáry Quarries with location of the studied interval near the Přídolí GSSP in the Požáry section.

slightly by including the snajdri Interval Zone as summarized by Corradini \& Serpagli 1999 and by Corradini (2009). Corradini (2009) highlighted the major problems when searching for a globally acceptable late Silurian standard conodont zonation. Corradini \& Barrick (2009) summarized the characteristics that every standard biozonation should possess. Particularly, the lack of "basic properties" of some "standard" zones is the main hindrance for their global application. Another condition that any standard zone should fulfil is its taxonomic and phylogenetic meaningfulness. Moreover, a rather slow progress in taxonomy has precluded substantial progress in the zonation that is almost fifty years old.

Conodont studies on the Ludfordian of Bohemia have been summarized by Slavík et al. (2010); the authors stated that the documentation of conodont data was rather scarce in past decades, although there existed extensive collections made by previous conodont workers (e.g., Walliser \& Schönlaub) and the present authors. Walliser (1964) was the first author who systematically studied conodonts from the Ludlow of the Prague Synform and the data he obtained were incorporated into his pioneer zonal framework. The conodont distribution and figures of specimens from the
Mušlovka and Koledník sections were presented by Schönlaub (in Chlupáč et al. 1980). Schönlaub (in Kříž et al. 1986) studied conodonts mostly from the LudlowPřídolí boundary interval in 10 stratigraphic sections (including e.g., Požáry, Mušlovka, Hvížd’alka, Koledník and Kosov). He reported the distribution of conodont indexes such as "Ozarkodina" snajdri and "Oz." crispa, and some other common taxa including Ozarkodina "confluens" (= Ozarkodina ex gr. typica) and "Ozarkodina" excavata (= Wurmiella excavata). The present paper follows up the studies by Carls et al. (2005) and Slavík et al. (2010) in order to complete the conodont biostratigraphy in the late Ludfordian interval in Bohemia.

After several sections in the Prague Synform have been studied, the Požáry section has been found to be the most suitable one for detailed conodont research of the Ludfordian strata. This implies the good accessibility of late Silurian strata where the GSSP for the Přídolí has been defined, the almost continuous succession with high density of manifold studies on biostratigraphy (e.g., Kříž et al. 1986), on bioevents (e.g., Manda \& Frýda 2010), on palaeoecology and palaeogeography (e.g., Manda 2008). It benefits from diversity and abundance of conodont faunas. 
Accordingly, the Požáry section (see Figs 1 and 2) may serve as a reference section for the conodont correlation of the Ludfordian in the Prague Synform.

\section{Locality of Požáry Quarries, sedimentological overview and previous conodont work}

The Požáry Quarries lie in the Prague Synform. In the sense of Melichar (2004) and Knížek et al. (2010) it is an asymmetric elliptical structural depression and erosional relic of unmetamorphosed Ordovician through Middle Devonian volcanic-sedimentary successions. The locality comprises the stratigraphic interval from Ludlow to Emsian. The Požáry Quarries are located E of Reporyje village (Fig. 1), at the WSW margin of Prague (GPS location: $50^{\circ} 01^{\prime} 43.92^{\prime \prime}$ and $14^{\circ} 19^{\prime} 38.74^{\prime \prime}$ for the GSSP of the Př́dolí Series). The area consists of several quarries and connecting tunnels. The section above the entrance tunnel is the GSSP locality of the Př́dolí Series (described in detail by Kříž et al. 1986) and particularly known as the Požáry section. The abandoned quarries are known in literature as Požár 1 and Požár 2; the section exposed in the western part of the active quarry is Požár 3 (Slavík et al. 2010). The interval sampled for the present study is within the protected part of the locality; it begins just above the northern mouth of the entrance tunnel and ends at the base of the Přidolí (i.e. the GSSP boundary) above the middle of the tunnel.

The history of studies of various stratigraphic intervals in the Požáry Quarries dates back to the early half of the $20^{\text {th }}$ century; it was briefly summarized in Slavík et al. (2010). The fundamental bed-by-bed study of the Ludlow-Přídolí interval was done by Kříž (1965, unpublished data). It includes detailed descriptions and numbering of beds. Data derived from it were the basis for the GSSP definition (Kř́ž et al. 1981, 1986); this numbering is applied also in this paper.

The Požáry section and the nearby very similar section at Mušlovka Quarry cover a part of the Reporyje Volcanic Elevation, which is the WNW part of the Ludfordian isolated carbonate platform in the eastern part of the Prague Basin, as interpreted by Manda \& Kř́̌ž (2006). The lithology of the Ludfordian from the upper part of the siluricus Zone to the base of the Př́dolí including the newly sampled interval of the Požáry section is shown in Fig. 2. The lithology of the underlying interval of the Požáry section, including the equivalent of the Lau Event, was summarized by Slavík et al. (2010). Massive grainstones (beds Nos. 33 and 34) contain fauna coeval to the N. kozlowskii graptolite Biozone. They are followed by mostly crinoidal grainstones with the Ananaspis fecunda trilobite horizon which first appears in bed No. 37. Lehnert et al. (2007) observed signs of paleokarst in the bed No. 33 and above, up to bed
No. 41; accordingly, extreme shallowing or even stratigraphic gaps can be expected in this interval. Thick-bedded biodetritic limestones (beds Nos. 42, 44), that represent a major part of the Lau Event interval in the Požáry section, are overlain by thinnner packstone beds with increasing contents of micrite. From the level of $19 \mathrm{~m}$ onward, the section consists of grey thin bedded packstones, subordinate siltstones and calcareous shales alternating with layers or lenses of grey lime-mudstones and packstones. Some limestone layers contain abundant trilobites (e.g., beds Nos. 60, 73, 75). Graptolites Pristiograptus dubius s.l. and "Monograptus" aff. kallimorphus are reported from calcareous shales in beds Nos. 86 and 88, Pristiograptus fragmentalis? was obtained only from the base of bed No. 93 (Kř́ž et al. 1986). According to Kříž (1992), the massive bed No. 87 (so-called "cephalopod bank") is the top bed of the Kopanina Formation. It contains very rich fauna with cephalopods, bivalves, ostracods and chitinozoans. The Požáry Formation begins just above this bed in the final Ludlow with mainly unsorted grainstones, packstones and carbonate mudstones (Kř́ž et al. 1986). Sorting of bioclasts within the uppermost Ludfordian beds may indicate storm deposits. The lithology and the faunal contents of the entire Ludfordian in the Požáry section reflect considerable fluctuation in depth like in other Ludfordian sections in the Prague Synform (Manda \& Kř́̌ž 2006, text-fig. 2).

Conodonts have been studied from several stratigraphical intervals of the Požáry Quarries (see summary by Slavík et al. 2012 in press). Conodonts from the post-Lau Event interval were included in the study by Mehrtens \& Barnett (1976), who reported index taxa including Pedavis latialatus and "Spathognathodus" snajdri. Schönlaub (in Kř́iž et al. 1986) provided conodont data from the Ludlow-Přídolí boundary interval from several sections including the Požáry section. He found the index taxa "Ozarkodina" snajdri and "Oz." crispa, the latter of which reached the base of the bed No. 91. Carls et al. (2005) showed further ranges of taxa in the late Ludfordian and discovered the innovative origin of alternating denticle size within Spathognathodontidae in Parazieglerodina plodowskii found in bed No. 62. Slavík et al. (2010) showed the conodont distribution around the Lau Event in the Požáry section. This paper continues the studies about the Lau Event in Bohemia based on additional conodont collections from the late Ludfordian.

\section{Material and methods}

The samples from the Požáry, Mušlovka and Kosov sections have been taken during campaigns in the last 10 years. They were collected in closely spaced intervals - mostly from the entire thickness of a solid carbonate bed (usually 15-20 cm thick) or from thicker intervals of thin beds 
(composite samples) as seen in Fig. 2. Weights of samples vary from 4 to $15 \mathrm{~kg}$. The rock was leached using standard techniques with formic or acetic acid in the laboratories of the Institute of Geology AS CR, v.v.i. and TU Braunschweig.

Voluminous residues (of up to $400 \mathrm{ml}$ ) dominated by siliceous particles were concentrated in tribrommethane. Residues with porous aggregates were treated with the upgraded magnetic susceptibility separation method (Carls \& Slavík 2005), which avoids using heavy liquids. Conodonts were obtained from all samples (i.e. more than 3000 complete or slightly fragmented elements). The SEM images of selected conodont elements were made by using a Tescan Vega 3 SEM. The conodont material from the Požáry Quarries is temporarily kept in the collections of L. Slavík and P. Carls at the Institute of Geology AS CR, v.v.i. and at the TU Braunschweig, respectively.

\section{Conodonts from the post-Lau Event interval in the Prague Synform}

The generic affiliations of some conodont taxa mentioned in this paper have been changed repeatedly, and the inclusion of some in a genus is doubtful. The latter genera are set in quotation marks because no better generic affiliation is presently possible. This is particularly the case of the genus "Ozarkodina" s.l.; e.g., taxa belonging to the crispa and snajdri stocks differ from the typical stock of the genus Ozarkodina Branson \& Mehl, 1933 s.s., but have only been quoted in it and have not yet been formally attributed to a convenient genus.

Mušlovka, Kosov, and Požáry sections, selected for the new sampling, partly confirmed previous data but also provided important new biostratigraphic information: Most samples from the Kosov section (for description and location see Kř́ž et al. 1986) furnished only few indeterminate fragments of conodonts; a fragment of P1 element of "Ozarkodina" crispa was found just below the LudlowPřídolí boundary (bed No. 19); it confirms the previous data of Schönlaub (in Kř́iž et al. 1986). Preliminary results obtained from 18 conodont samples from the Mušlovka section extended the previous knowledge provided by Schönlaub (in Chlupáč et al. 1980). The new samples were taken mostly from previously unsampled levels or parts of beds in order to complete the information on conodont ranges. The Mušlovka section lies about $700 \mathrm{~m}$ east from the Požáry section. Both sections have similar lithologies, however, the thicknesses of some horizons vary slightly. For a detailed description of the Mušlovka section see Kř́ž (in Chlupáč et al. 1980). The "traditional" stratigraphically important taxa as Polygnathoides siluricus, "Ozarkodina" snajdri and "Oz." crispa were found in the Mušlovka section, and, most importantly, also Parazieglerodina plodowskii Carls et al., 2005 was obtained. The conodont data from the repeated samplings of the late Ludfordian of the Požáry section is presented herein with special attention because it is considered the most representative set within the entire Prague Synform.

The preservation of conodont elements in the majority of the samples is fair. Only in the sample PZ015 all elements are thoroughly bleached and are of whitish colour. In contrast to the underlying siluricus Zone, the basal filling is not preserved in any conodont element. The following characterization of the conodont material does not only consider taxonomical affinity, but also looks out for possible relations between morphology and susceptibility for environmental effects on conodontophorid life.

\section{Plain spathognathodontids}

A group of taxa represented by rather delicate P1 elements, which are notably smaller than other late Ludfordian Spathognathodontidae, are herein informally addressed as "slender spathognathodontids" (see Figs 3-7). Most P1 elements can be attributed to the established taxa. Several specimens could not be classified with certainty, neither to specific nor to generic level; their distribution at Požáry is marked as Zieglerodina? sp. Apart from Wurmiella, the first spathognathodontid taxon that appears after a long interval with only monotonous conodont faunas around the Lau Event is Parazieglerodina plodowskii Carls et al., 2005, which is characterized by incipient alternating denticulation in some ramiform elements. This morphological innovation probably reflects a new function of the ramiform elements in the post-Lau Event development of conodonts, which tested the new morphologies for feeding apparatuses. The entry of this taxon is found herein $1.3 \mathrm{~m}$ lower than it was found by Carls et al. (2005). In the Požáry

Figure 2. Stratigraphic section with sampled interval comprising the upper Ludfordian including the equivalents of the Lau Event and the post-Lau Event time in the Požáry Quarries. The figure shows the distribution of the most important conodont taxa and numbers of conodont elements (e.g., "3P1" means 3P1 elements in the sample, "18el" means 18 conodont elements of different kinds belonging to the taxon in the sample). Element frequency in samples is based on the total number of conodont specimens, and relative conodont diversity is based on the quantity of determined taxa (undetermined elements were not considered in the graph). The bed numbers are adopted from Křiž et al. (1986) and Kříž (1965, unpublished part of the Požáry section). Lithology legend: 1 - grey lime-mudstones and biodetritic packstones; 2 - bioclastic grainstones with cephalopods, bivalves or brachiopods; 3 - thin-bedded packstones and subordinate siltstones and calcareous shales alternating with layers or lenses of grey lime-mudstones and packstones. 
Ladislav Slavík \& Peter Carls • Post-Lau Event (late Ludfordian, Silurian) recovery of conodont faunas of Bohemia

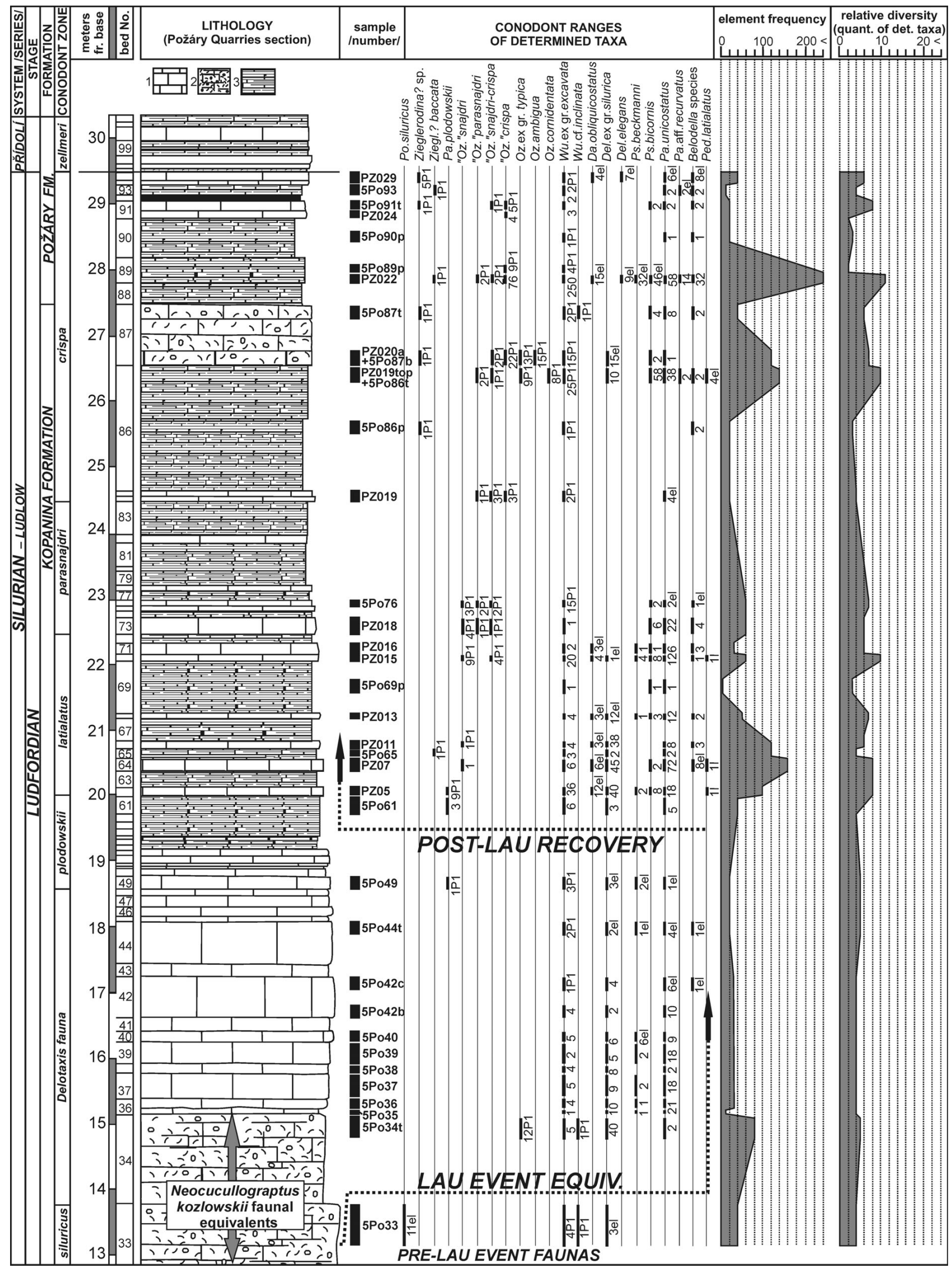


section it enters in bed No. 49 (sample 5Po49). In the Mušlovka section it was obtained only from bed No. 22 (sample $9 \mathrm{MU})$. As the recorded range in the Požáry section shows (Fig. 2), Parazieglerodina plodowskii is a short range taxon that probably precedes the entry of "Oz." snajdri and thus may be stratigraphically significant in the Barrandian.

Only three P1 elements of Zieglerodina? baccata (Miller \& Aldridge, 1997) were obtained from three samples of the late Ludfordian in the Požáry section. The apparatus of Z.? baccata has not yet been reconstructed, but few associated fragments of ramiform elements with alternation from the Požáry section point to a similarity with the apparatus of Zieglerodina Murphy et al., 2004. This taxon has been reported from the Upper Whitcliffe Formation from Wales (Miller \& Aldridge 1997) and from the Kuressaare Stage in East Baltica (Viira 1999).

\section{Ozarkodina s.s.}

The characteristic species of Ozarkodina s.s. generally have unsteady distributions in many sections and regions. The representatives of the genus Ozarkodina Branson \& Mehl, 1933 disappeared from the Prague Synform during the Lau Event and re-appeared thereafter. Following the revision by Murphy et al. (2004), only the taxa belonging to Ozarkodina ex gr. typica are considered herein to fall into Ozarkodina. The P1 elements of Ozarkodina are characterized by a high anterior cockscomb set off from the rest of the element; the basal cavity is centered very near the mid-length of the blade, the basal cavity and the platform lobes are very small. There is a very long interruption in the occurrence of Ozarkodina from the top of the bed No. 34 up to the top of bed No. 86, where it reappears and ranges in a very short interval. The same range of Ozarkodina can be seen in the equivalent section Mušlovka, where Ozarkodina is absent from $1 \mathrm{~m}$ above the last occurrence of Polygnathoides siluricus onward. Its massive re-appearance then starts from bed No. 33a which is the base of the "cephalopod bank" known from several sections around the Prague Synform ( $c f$. Kř́̌ž et al. 1986). The new sampling did not furnish any occurrence of Ozarkodina s.s. between these levels. The material obtained from four samples taken around the boundary of beds Nos. 86 and 87 in the Požáry section shows certain variability, but the specimens are not variable to the high degree as during the siluricus Zone ( $c f$. Slavík et al. 2010, fig. 5). Several P1 elements of Ozarkodina obtained from the top of bed No. 86 can be assigned to Ozarkodina cornidentata (Viira, 1983). This taxon has been described from the Paadla Stage in East Baltica and, according to Viira (1999), is characterized by $2-3$ big posteriorly inclined denticles in the central-posterior part of the blade. The specimens vary in the inclination of denticles, which is not always so distinct as shown by Viira
(1999, pl. 2, figs 5, 6). Therefore some specimens are treated herein in open nomenclature. The specimen of Fig. 7B represents the typical morphology of Ozarkodina cornidentata; it was found only at the top of bed No. 86. Ozarkodina ambigua (Viira, 1983) occurs only just above, in the basal part of bed No. 87. This taxon from the Kuressaare Stage in East Baltica is characterized by a convex posterior part of the blade and a regular anterior cockscomb with at least three unfused denticles (see Fig. 70). Similar morphology of the blade occurs also in other taxa and in other regions but are not identical: The specimen figured by Corriga \& Corradini (2009, fig. 4L) from the snajdri Zone in the Carnic Alps seems to be very close to Oz. ambigua because of its irregular denticle sizes. The character of the cockscomb, degree of fusion of denticles and their inclination is also variable in our Ozarkodina s.s. and therefore, many specimens from the Požáry section cannot be unambiguously attributed to the species of Ozarkodina s.s. mentioned above. Accordingly, a number of specimens from both levels is here treated as Ozarkodina ex gr. typica-i.e. a group of taxa with general morphology of Ozarkodina s.s. According to Carls et al. (2007), in the Požáry section, Ozarkodina typica s.s. appears $20 \mathrm{~cm}$ above the base of Přídolí. The genus reached the very end of the Silurian, but did not cross the Silurian-Devonian boundary.

\section{"Ozarkodina" of the snajdri-crispa group}

As mentioned above, spathognathodontid taxa of the crispa and snajdri stocks cannot belong to the genus Ozarkodina s.s. This may be stated, although their apparatusses remain unknown. The morphological difference of their P1 elements from Ozarkodina is substantial: e.g., lack of anterior cockscomb, far posterior extension of basal lobes. These taxa were reported from many parts of the world including Australia (see review by Simpson 1995) as Ozarkodina. Following the discussion in Murphy et al. (2004), we maintain the traditional generic attribution to Ozarkodina in quotation marks, only because no other genus name is available. We suggest that a genus should be typified by a species whose apparatus could largely be characterized.

The material of the "Ozarkodina" snajdri-crispa group obtained from the Požáry and Mušlovka sections can be attributed to four taxa based on the P1 elements. The oldest "Oz." snajdri enters just above the last Parazieglerodina plodowskii (sample PZ07, bed No. 64, Požáry section; sample 10MU, bed No. 23, Mušlovka section). The range of "Oz." snajdri is relatively short in both sections (approximately $2.5 \mathrm{~m}$ interval). In the upper range it overlaps with "Oz." parasnajdri Viira \& Aldridge, 1998. According to its diagnosis, "Oz." parasnajdri differs from "Oz." snajdri by characteristic fusion of denticles above its platform. All of Walliser's figured type specimens of snajdri have discrete 


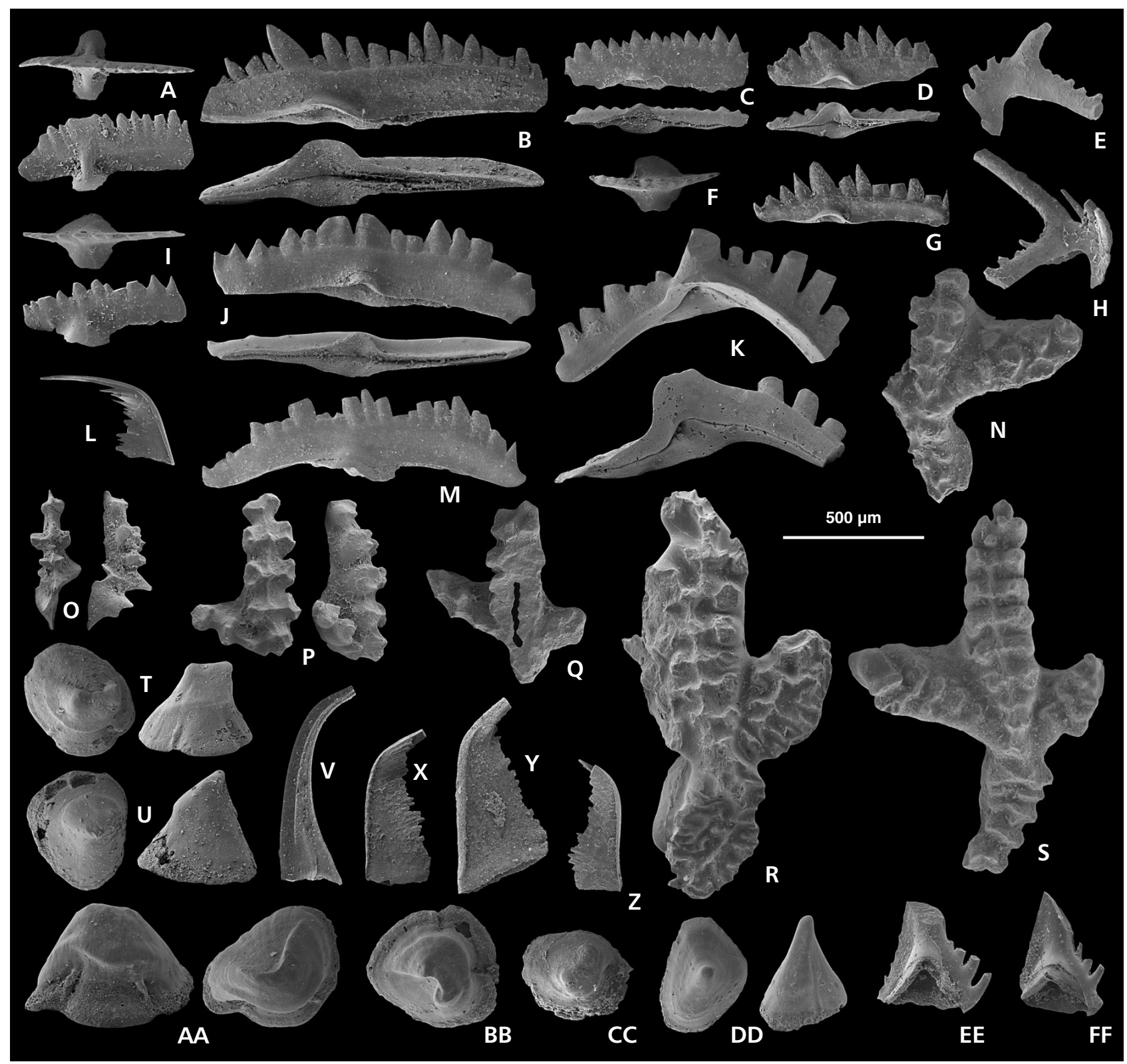

Figure 3. A - Parazieglerodina plodowskii Carls et al., 2005; upper and lateral view of P1 element, sample 5Po61. • B, D, G, M - Wurmiella excavata (Branson \& Mehl, 1933) sensu lato. $\bullet$ B - lateral and lower view of P1 element, sample 5Po61. •D - lateral and lower view of immature P1 element, sample PZ015. • G - lateral view of P1 element, sample PZ015. • M - lateral view of P1 element, sample 5Po93. • C - Wurmiella ex gr. excavata (aff. alternata Corradini \& Corriga, 2010); lateral and lower view of P1 element, sample 5Po93. • J - Wurmiella cf. inclinata (Rhodes, 1953); lateral and lower view of P1 element, sample 5Po87t. E, H - Delotaxis elegans (Walliser, 1964), inner lateral views of S2 elements, sample PZ022. • F-Zieglerodina? cf. baccata (Miller \& Aldridge, 1997), upper view of immature P1 element, sample 5Po93. • I-Zieglerodina? baccata (Miller \& Aldridge, 1997), upper and lateral view of P1 element, sample 5Po65. $• \mathrm{~K}$ - Delotaxis ex gr. silurica (Branson \& Mehl, 1933), outer lateral and lower view of P2 element, sample PZ07. $\bullet \mathrm{L}, \mathrm{Y}-$ Belodella aff. anomalis Cooper, 1974 . $\bullet \mathrm{L}-$ lateral view, sample PZ019top. $\bullet \mathrm{Y}-$ lateral view, sample 5Po87t. $\bullet \mathrm{N}-\mathrm{S}, \mathrm{EE}, \mathrm{FF}-$ Pedavis latialatus (Walliser, 1964). $\bullet \mathrm{N}$ - upper view of incomplete I element, sample PZ019top. $\bullet \mathrm{O}-$ upper and lateral view of immature I element, sample PZ05. $\cdot \mathrm{P}$ - upper and lateral view of incomplete immature I element, sample PZ07. $\bullet \mathrm{Q}-$ upper view of incomplete I element, sample PZ015. $\bullet \mathrm{R}-$ upper view of incomplete I element, sample PZ019top. • S - upper view of I element, sample PZ019top. • EE - lateral view of uncertain element, sample PZ019top. $\cdot \mathrm{FF}$ - lateral view of uncertain element, sample PZ019top. $\bullet \mathrm{T}$, AA-CC - Pseudooneotodus bicornis Drygant, 1974. $\bullet \mathrm{T}$ - upper and lateral view, sample 5Po76. - AA - lateral and upper view, sample PZ019top. - BB - upper view, sample PZ019top. - CC - upper view, sample PZ016. $\cdot \mathrm{U}, \mathrm{DD}-$ Pseudooneotodus beckmanni (Bischoff \& Sannemann, 1958). $\bullet \mathrm{U}$ - upper and lateral view, sample 5Po61. $\bullet$ DD - upper and lateral view, sample PZ019top. $\bullet \mathrm{V}-$ Panderodus unicostatus (Branson \& Mehl, 1933); lateral view, sample 5Po61. $\bullet \mathrm{X}, \mathrm{Z}-$ Belodella cf. resima $($ Philip, 1965$) \cdot \boldsymbol{X}-$ lateral view, sample 5Po65. $\mathrm{Z}$ - lateral view, sample 5Po93. All specimens are deposited in the collections of Ladislav Slavík at the Institute of Geology AS CR, v.v.i. and Peter Carls at the Technische Universität Braunschweig. All figures are the same scale (scale bar equals $500 \mu \mathrm{m}$ ). 
denticles throughout the blade. The platform of "Oz." parasnajdri has a sub-quadrangular shape like in snajdri but unlike crispa where it is oblique. The taxon parasnajdri is treated herein on specific level (not as a subspecies) because of the difference in denticulation between snajdri and parasnajdri.

The entry of "Oz." crispa was recorded in sample PZ019 (beds Nos. 84 and 85) in the Požáry section, i.e. $5 \mathrm{~m}$ below the base of the Prrídolí. The new sampling revealed an earlier entry of "Oz." crispa (sample 13MU, bed. No. 32) in the Mušlovka section than formerly reported by Schönlaub (in Chlupáč et al. 1980); this entry is equivalent to that in the Požáry section. The specimens of "Oz." crispa obtained are highly variable (see Figs 4 and 5). Four morphotypes (alpha, beta, gamma and delta) of crispa were discriminated by Walliser \& Wang (1989). Additionally, Viira \& Aldridge (1998) further distinguished sub-morphotypes of the typical alpha morphotype, the only one that lacks a "sulcus" (furrow) on the oral margin of the blade. Similarly, like in Baltica, all obtained specimens from the Prague Synform can be attributed to the alpha group of morphotypes. According to Viira \& Aldridge (1998), some specimens belong to morphotype alpha2 (see Fig. 5B, H-J) in which the basal cavity is sub-circular and the denticles of the blade above the basal cavity are fused. In morphotype alpha3 (see Fig. 5C, L, P) the denticles above the basal cavity are only partly fused or unfused. The stratigraphical ranges of these morphotypes overlap completely; in all samples they are present together. Therefore, the stratigraphic utility for a refined subdivision is not yet certain. The material attributed to the snajdri-crispa group contains many transitional forms. Accordingly, there are many specimens left in open nomeclature (cf. Figs 4 and 5): in "Ozarkodina" cf. parasnajdri and in "Oz." cf. snajdri the denticles are only partly fused; "Ozarkodina" snajdri-crispa is the characteristic transitional form which has an undulated (wavy) platform like in typical crispa, but the end of the blade comes out like in snajdri. These transitional specimens are present in a thick interval starting from bed No. 70 in the Požáry section.

\section{Icriodontids}

Icriodontids are represented by Pedavis latialatus (Walliser, 1964). The new sampling confirmed its occurrence only in the Požáry section. Schönlaub (in Křiž et al. 1986) reported Ped. latialatus also from the sections of Koledník, Kosov, Marble Quarry, and Mušlovka. Although Pedavis is very scarce in the sections of the Prague Synform, in the Požáry section this stratigraphically important lineage has the longest range documented. Its stratigraphic range even exceeds the range of "Oz." snajdri. It confirms that the conodont record in the Požáry section is the most complete and representative in the Prague Synform. The oldest specimens are from bed No. 62 (sample PZ05). The material of Pedavis obtained from the Požáry section includes both mature and immature I elements. Classification of small I elements is not always unambiguous, however, the attribution to Ped. latialatus is likely because of the stratigraphic position of these oldest Pedavis for which only one species has been erected as yet. Apart from platform elements, some other associated elements of the Pedavis apparatus were found in sample PZ019top (see Fig. 3EE, FF), i.e. the youngest sample where this taxon occurs.

\section{Wurmiella}

The genus Wurmiella Murphy, Valenzuela-Ríos \& Carls, 2004 is the most commonly represented one in the Ludfordian as regards P1 elements of Spathognathodontidae. Taxa belonging to Wurmiella are present in all samples in the Požáry and Mušlovka section. The genus shows maximum resistance against sea-level fluctuation and other palaeoenvironmental changes and whatsoever effects of the Lau Event. In Wurmiella, the post-Lau Event development consists in characteristic shortening of P1 elements and by decrease of the number of denticles. The post-Lau Event specimens have usually 4 to 5 denticles less than the adult P1 elements of Wu. excavata from the siluricus Zone. Diversity of P1 elements is also higher than in the preceding siluricus interval. Most of the specimens obtained from the new sampling belong to Wurmiella excavata (Branson \& Mehl, 1933) s.l. We refer to this stock sensu lato because of marked differences in the angulation of the aboral margin and of the denticulation between the typical material from the Bainbridge Limestone (Branson \& Mehl 1933) and the material obtained from the Požáry and Mušlovka sections. The concept of Wurmiella and the apparatus reconstruction herein agrees with that of Murphy et al. (2004); representative selections of elements of the apparatus of Wurmiella are figured on Figs 3 and 6. In the material from the Požáry section, a few specimens are similar to a taxon just recently established: Wurmiella aff. alternata Corradini \& Corriga, 2010 of Fig. 3C was obtained from bed No. 93 in the Požáry section. It is characterized by a straight aboral margin and intercalation of single small denticles between larger ones along the blade. The denticles are straight and without inclination that is typical for most other specimens of Wurmiella. The taxon $W u$. alternata has been described from the Carnic Alps from the lower Přídolí. Four specimens obtained from the uppermost Ludlow of the Požáry section may represent the same taxon or its ancestor. The distribution of diverse forms of the $W u$. excavata group from the Požáry section is indicated in Fig. 2 as Wurmiella ex gr. excavata. Only few P1 elements of Wurmiella were classified to Wurmiella cf. inclinata (Rhodes, 1953); their spacing of 


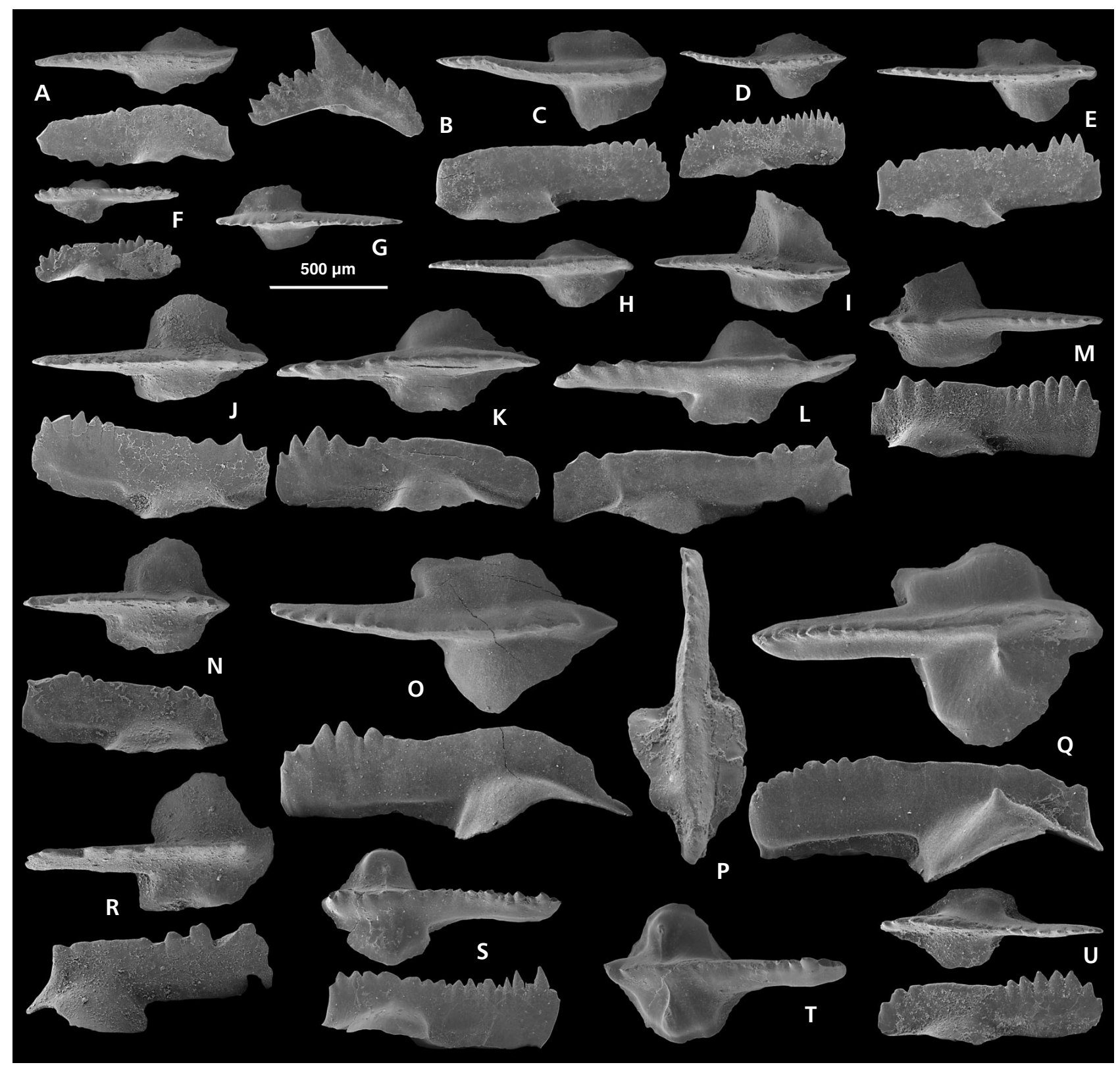

Figure 4. A, B, D, F, G, H, J, M - "Ozarkodina" snajdri (Walliser, 1964). • A - upper and lateral view of P1 element, sample PZ07. • B - lateral view of P2 element, sample PZ07. • D - upper and lateral view of P1 element, sample PZ015. $\bullet$ F - upper and lateral view of small P1 element, sample PZ07. - G - upper view of P1 element, sample PZ015. • H - upper view of P1 element, sample PZ015. • J - upper and lateral view of P1 element, sample PZ018. - M - upper and lateral view of P1 element, sample PZ018. E, N - "Ozarkodina" cf. snajdri (Walliser, 1964). E - upper and lateral view of P1 element, sample PZ015. $\bullet \mathrm{N}$ - upper and lateral view of P1 element, sample PZ018. $\bullet$ C, I, O, Q, S - "Ozarkodina" snajdri-crispa. $\bullet$ C - upper and lateral view of P1 element, sample PZ015. $\bullet \mathrm{I}$ - upper view of P1 element, sample PZ015. $\bullet \mathrm{O}$ - upper and lateral view of P1 element, sample 5Po076. $\bullet \mathrm{Q}-$ upper and lateral view of P1 element, sample PZ019. • S - upper and lateral view of P1 element, sample PZ019top. $\bullet \mathrm{K}, \mathrm{L}, \mathrm{U}$ - "Ozarkodina" parasnajdri Viira \& Aldridge, 1998. $\bullet \mathrm{K}$ - upper and lateral view of P1 element, sample PZ018. $\bullet \mathrm{L}$ - upper and lateral view of P1 element, sample PZ018. $\bullet \mathrm{U}-$ upper and lateral view of P1 element, sample PZ019top. • P - "Ozarkodina" cf. parasnajdri Viira \& Aldridge, 1998, upper view of P1 element, sample PZ019top. - R - "Ozarkodina" crispa (Walliser, 1964), upper and lateral view of P1 element, sample PZ019. • T - "Ozarkodina" aff. crispa (Walliser, 1964), upper view of P1 element, sample PZ019top. All specimens are deposited in the collections of Ladislav Slavík at the Institute of Geology AS CR, v.v.i. and Peter Carls at the Technische Universität Braunschweig. All figures are the same scale (scale bar equals $500 \mu \mathrm{m}$ ).

denticles is similar to that of the specimen figured by Rexroad \& Craig (1971, pl. 80, fig. 25), which was designated as the neotype of Wu. inclinata by Murphy et al. (2004, p. 10). The specimen figured in Slavík et al. (2010, fig. 6U) from the siluricus Zone is immature, but the specimen from the younger top of bed No. 87 (Fig. 3J herein) is mature. 
These specimens are treated in open nomenclature because their lower margins are almost even, which differs from Wu. inclinata.

\section{Delotaxis}

The populations of Delotaxis Klapper \& Philip, 1971 were very successful components of conodont faunas during the Lau Event. Following the discussion in Slavík et al. (2010), the use of the genus name Delotaxis for the late Silurianearly Devonian group of prioniodinid taxa is preferred herein rather than the name "Oulodus Branson \& Mehl, 1933". The distribution of Delotaxis in the Mušlovka section is similar to that in the Požáry section shown in Fig. 2. Elements of Delotaxis ex gr. silurica were found together with Po. siluricus and were frequent already during the early post-Lau Event time, when there were no other apparatuses of composite elements besides Wurmiella. Then they co-occurred only briefly with the just originating new spathognathodontids (i.e. Pa. plodowskii, Z.? baccata and "Oz." snajdri). Suddenly Delotaxis showed, however, a marked decrease at the massive entry of the "Oz." snajdri stock, i.e. the interval between samples PZ015 and 5Po76 (see Fig. 2). From this level onward, the elements of Delotaxis disappear for a long interval, probably as a result of dominance of spathognathodontid competitors. The re-appearance of Delotaxis was found in the top of bed No. 86 in the Požáry section (Fig. 2). The material from the post-Lau Event interval is in general rather poor and often fragmented. Accordingly, the specific determination is difficult. Most of the specimens probably belong to Delotaxis ex gr. silurica (Branson \& Mehl, 1933; see Fig. 3K). Close to the end of the Ludlow the silurica group is replaced by Delotaxis elegans (Walliser, 1964). Only few complete specimens of D. elegans were obtained (Fig. 3E, H). Also in the East Baltic erratics the elegans stock begins to abound in the late Ludfordian.

\section{Coniform elements}

Simple cone elements were much more abundant during the Lau Event and post-Lau Event interval than during the siluricus Zone. The increasing presence of coniform elements is the dominating success of conodont faunas and it corresponds with their recovery after the Lau Event. Three genera abound first: Pseudooneotodus, Panderodus and Belodella; Dapsilodus joins them in the plodowskii Zone. Selected coniform elements are figured in Fig. 3. The specific identifications ( $c f$. Figs 2 and 3), however, are still more or less tentative. Belodella from the Mušlovka and Požáry sections includes several taxa close to B. anomalis Cooper, 1974 and B. resima (Philip, 1965).
Pseudooneotodus start to occur in higher numbers in the late Ludfordian as shown by Corradini (2007, fig. 2); the same is the case in the Prague Synform. Pseudooneotodus bicornis Drygant, 1974 occurs from bed No. 62 onward and is the most frequent coniform element in the late Ludfordian. The stratigraphic significance of some delicate simple cone elements (e.g., Belodella) is, in general, rather low; as their frequency in samples may largely depend on depositional conditions (e.g., hydrodynamic sorting of sediment particles).

\section{Summary of biostratigraphic data from the late Ludfordian in the Prague Synform}

To summarize, the conodont data from the late Ludlow in the Prague Synform provide an image of stepwise increase of conodont diversity that starts already below the recorded entry of Pedavis latialatus. It corresponds also to the restoration of benthic and nektobenthic faunas correlated with the upper part of the Pseudomonoclimacis latilobus-Slovinograptus balticus graptolite Biozone Zone and is connected with a moderate sea-level rise ( $c f$. Manda \& Kř́žž 2006, Manda et al. 2012). After an interval of low diversity with long-ranging ubiquists the entry of slender spathognathodontids (e.g., Parazieglerodina plodowskii) is the dawn of conodont proliferation in the Požáry and Mušlovka sections. These localities belonged to the former volcanic elevation during the mid-Ludfordian and were affected by fluctuations of sea-level that also could reduce the completeness of the biostratigraphical record. The index taxon Pedavis latialatus is, as usual, very rare and it has been recorded by new sampling only in the Požáry section. Accordingly, in other sections the latialatus time is correlated indirectly - using the snajdri and crispa stocks. Schönlaub (in Chlupáč et al. 1980 and in Kř́ž et al. 1986) provided already basic conodont information (the ranges of the taxa snajdri, crispa, typica and excavata) of the Ludlow-Přídolí boundary interval from sections in the Prague Synform. According to the former and the new data, "Ozarkodina" crispa was documented to disappear closely below the Ludlow-Př́dolí boundary.

The correlation of conodont and graptolite faunas within the late Ludfordian of the Prague Synform would be welcome, but it is difficult due to the facies-control of occurrences and absences of graptolites in limestone dominated sections. Reference to graptolite ranges is mostly indirect, being based on the distribution of benthic and nektobenthic faunas (e.g., Kř́iž 1991, Manda \& Kř́̌̌z 2006). According to Kř́ž et al. (1986) graptolite data from the predominately carbonatic successions of the late Ludfordian are extremely scarce; this is in contrast to the Přídolí where 


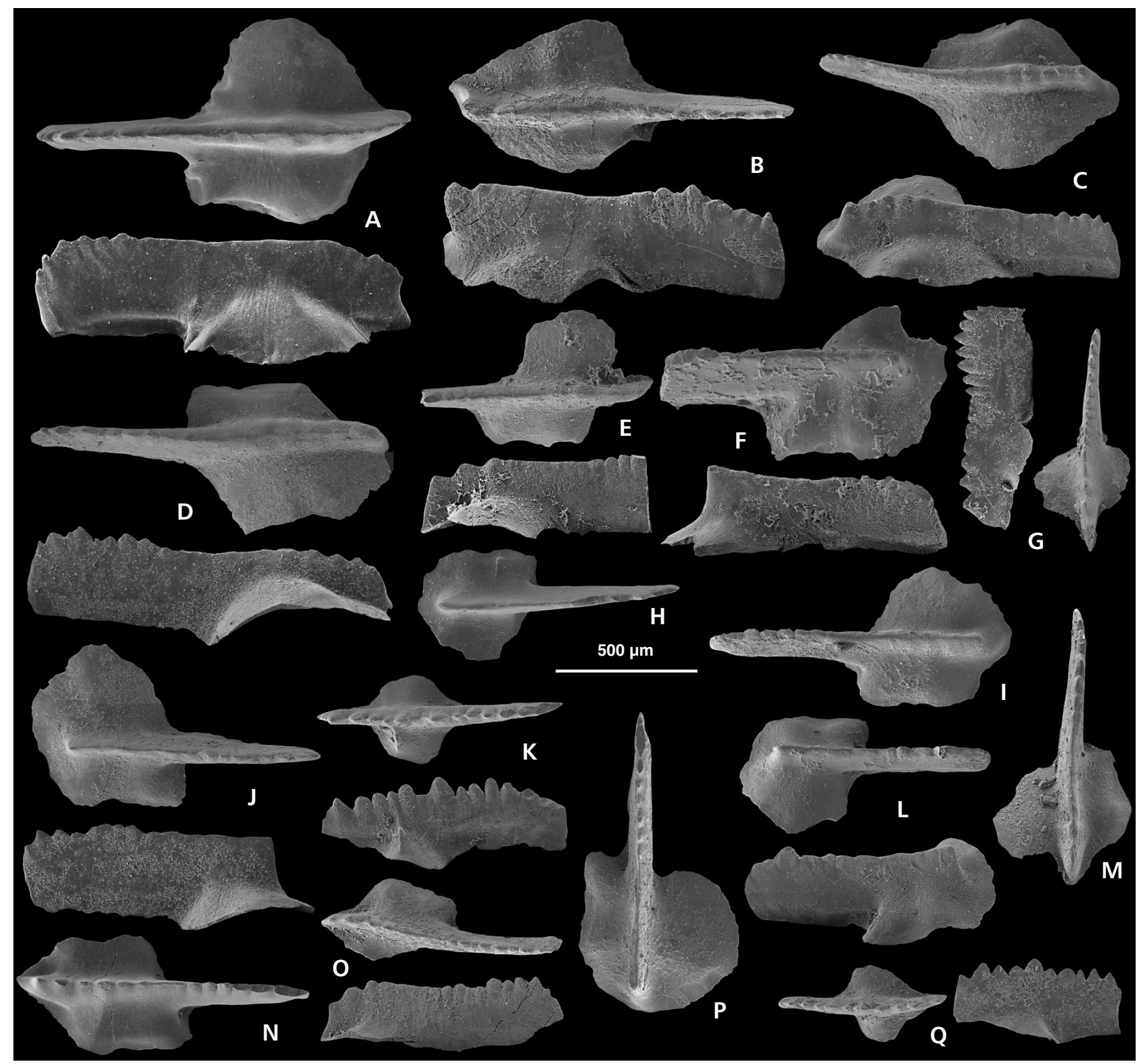

Figure 5. A, D, M, N - "Ozarkodina" snajdri-crispa. • A - upper and lateral view of P1 element, sample PZ019top. $\bullet \mathrm{D}-$ upper and lateral view of P1 element, sample PZ020a. • M - upper view of P1 element, sample PZ022. • N - upper view of P1 element, sample PZ022. • B, C, F, H, I, J, P, L "Ozarkodina" crispa (Walliser, 1964); B - alpha2 morph sensu Viira \& Aldridge, 1998, upper and lateral view of P1 element, sample PZ020a. - C - alpha3 morph sensu Viira \& Aldridge, 1998, upper and obliquely lateral view of P1 element, sample PZ020a. • F - alpha1 morph sensu Viira \& Aldridge, 1998, upper and lateral view of P1 element, sample PZ022 • H - alpha2 morph sensu Viira \& Aldridge, 1998, upper view of P1 element, sample PZ022. • I - alpha2 morph sensu Viira \& Aldridge, 1998, upper view of P1 element, sample PZ022. • J - alpha2 morph sensu Viira \& Aldridge, 1998, upper and lateral view of P1 element, sample PZ022. • P - alpha3 morph sensu Viira \& Aldridge, 1998, upper view of P1 element, sample PZ022. - L - alpha3 morph sensu Viira \& Aldridge, 1998, upper and lateral view of P1 element, sample PZ022. • E, O - "Ozarkodina" parasnajdri Viira \& Aldridge, 1998. • E - upper and lateral view of incomplete P1 element, sample PZ022. • O - upper and lateral view of P1 element, sample PZ022. - G, Q - "Ozarkodina" cf. parasnajdri Viira \& Aldridge, 1998. • G - lateral and upper view of P1 element, sample PZ022. $\bullet$ - upper and lateral view of small P1 element, sample PZ022. $\mathrm{K}$ - Zieglerodina? baccata (Miller \& Aldridge, 1997), upper and lateral view of P1 element, sample PZ022. All specimens are deposited in the collections of Ladislav Slavík at the Institute of Geology AS CR, v.v.i. and Peter Carls at the Technische Universität Braunschweig. All figures are the same scale (scale bar equals $500 \mu \mathrm{m}$ ).

a fine graptolite zonation has been developed. In the Požáry section the sole latest Ludfordian index graptolite Pristiograptus fragmentalis? (sic with question mark) was documented from only one bed (base of bed No. 93, Křǐz et al. 1986, fig. 8). This occurrence is problematic, as it seems to be rather delayed, if one considers the following 
relations: Manda \& Frýda (2010) subdivided the late Silurian-early Devonian interval in the Prague Synform into several "time slices". With respect to the late Ludlow, their "Time slice A" corresponds to the Monograptus fragmentalis graptolite Zone of Kř́ž (1998) which can be approximated with the Prionopeltis archiaci trilobite Horizon of Horný (1955). At Mušlovka, the Time slice A can be indirectly correlated with the late Ludfordian interval from bed No. 28 (Kříž 1992); in the Požáry section, the corresponding interval begins from bed No. 75 (J. Kř́̌ž, pers. comm.). This boundary corresponds roughly to the base of the parasnajdri Zone. Although data on graptolites and chitinozoans are excellent for the identification of the base of the Př́dolí, the finer subdivision of the post-siluricus interval that includes the rest of the Ludfordian time can be, however, made in the meantime only by conodonts.

\section{Conodont biostratigraphy}

There were several attempts to subdivide the Ludfordian. However, very conservative conodont taxonomy resulted in a slow progress of biostratigraphic subdivision. As regards the late Silurian, the recent introduction of "Stage slices" by Cramer et al. (2011) cannot be always considered as a step forward in knowledge because it only recycles and combines the outdated concepts and implies errors (e.g., including the entire ploeckensis Zone into the Ludfordian, problematic use of the snajdri Interval Zone to define the middle Ludfordian or even placing the origin of the Devonian genus Icriodus into the Silurian). As already mentioned in the introduction, since the pioneer Silurian conodont framework by Walliser (1964), there have been only slight modifications for the late Silurian, including the problematic snajdri Interval Zone (Nowlan 1995) that has been later included in the proposal for the global standard (Corradini \& Serpagli 1999, p. 266).

According to Slavík et al. (2010) only the younger part of the Lau Event is represented in the shallow water environment of the former Reporyje Volcanic Elevation. The immediate post-siluricus interval is characterized by rather poor conodont faunas dominated by Delotaxis and Wurmiella that do not allow establish a useful biostratigraphical unit, that might be correlated positively elsewhere. It is because that the ranges of the poorly delimited taxonomic groups are too long for this purpose. The conditions improve, however, $5 \mathrm{~m}$ above the range of Po. siluricus in the Požáry section. The detailed documentation of the post-Lau Event conodont recovery from the Požáry section, with support through data from other sections, enables the delimitation and positive characterization of the following conodont biozones in the late Ludfordian that have, at least, a regional significance:

\section{The plodowskii Bizone}

Parazieglerodina plodowskii Carls et al., 2005 is the index for the beginning of the regional conodont biozone as introduced herein. The base of the Zone is defined by the entry of the nominate taxon and the end is defined by the entry of Pedavis latialatus (Walliser, 1964). The wider geographic distribution of the taxon Pa. plodowskii and its range in other areas has still to be proven; in the meantime, this zone serves only for intra-regional correlation. The index taxon enters before the recorded range of "Ozarkodina" snajdri. Possible gaps in sedimentation mentioned by Slavík et al. (2010) above the recorded siluricus range might suggest a possibly earlier entry. But this is not likely: the long interval with the P. siluricus Zone within the presumed $N$. kozlowskii graptolite Zone on Gotland (Jeppsson et al. 2006, text-fig. 1) and the short range of siluricus without Kockelella in Bohemia (in contrast to Gotland) rather indicates the absence of a long upper part of the P. siluricus Zone in the Požáry and Mušlovka sections. On the other hand, the absence of substantial parts of the ranges of $\mathrm{Pa}$. plodowskii, "Oz." snajdri or Ped. latialatus is not likely because these taxa entered when the sea-level was already rising (see discussion in Slavík et al. 2010, p. 410). Accordingly, the recorded entries of these taxa which are well above the interval affected with gaps thus may be close to their real origins. The earlier entry of "Oz." snajdri reported by Schönlaub (in Chlupáč et al. 1980) from the Mušlovka section cannot be verified neither by the new sampling nor by study of the original material deposited in the Geological Survey of Austria (L. Slavík). On the other hand, the new sampling confirmed the entry of "Oz." snajdri approximately at the same level (about $7 \mathrm{~m}$ above the last occurrence of Polygnathoides siluricus) in both equivalent sections (Mušlovka and Požáry). Until new (contrasting) data are available, the entry of $P a$. plodowskii is considered older than the entries of "Oz." snajdri and Ped. latialatus.

\section{The latialatus Biozone}

The zone is delimited by the entry of the nominate index taxon and its upper limit is the entry of "Ozarkodina" $p a$ rasnajdri Viira \& Aldridge, 1998. The relation between the entries of Pedavis latialatus and "Oz." snajdri was discussed by Schönlaub (in Kř́̌ž et al. 1986) who documented the co-occurrence of both taxa in their early range. He reported P. latialatus from the Marble Quarry to appear below "Oz." snajdri. Also in the Požáry section, Pedavis latialatus was documented to enter earlier. Like in the Cellon section, the fauna with Pedavis latialatus can be correlated with the Icriodontid Subzone on 


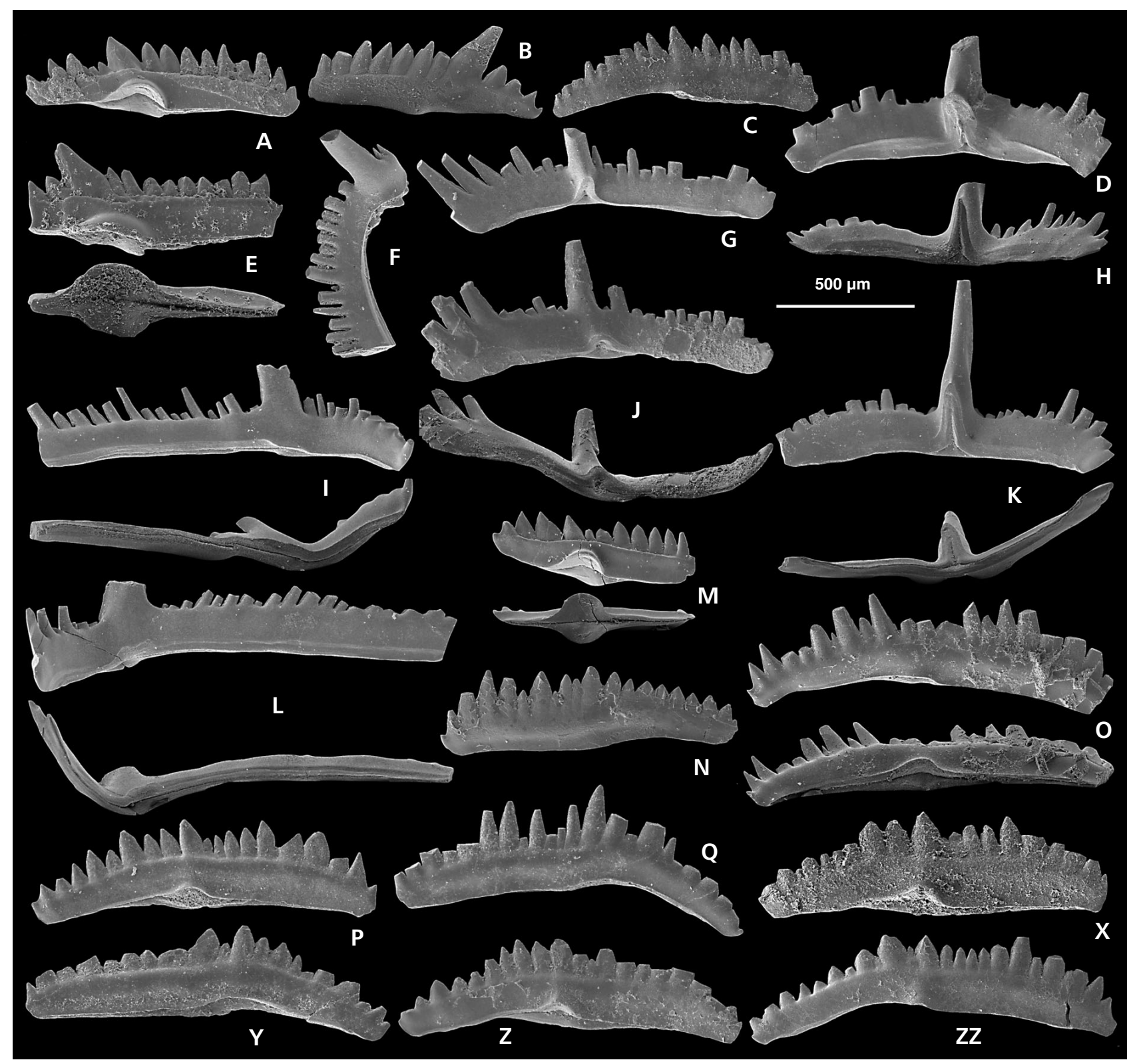

Figure 6. Wurmiella excavata (Branson \& Mehl, 1933) sensu lato. $\bullet$ A - lateral view of P1 element with large basal lobes, sample PZ019. $\bullet$ B - lateral view of paucidentate P1 element, sample PZ016. $\bullet \mathrm{C}$ - lateral view of P1 element, sample PZ019top. $\bullet$ D - postero-lateral view of S0 element, sample PZ019top. • E - lateral and lower view of incomplete P1 element, sample PZ019top. $\bullet \mathrm{F}$ - lateral view of M element, sample PZ019top. $\bullet \mathrm{G}-$ lateral view of S1 element with short basal cavity, sample PZ019top. $\bullet$ H - lower view of S0 element, sample PZ019top. $\bullet$ I - inner-lateral and lower view of S2 element, sample PZ019top. • J - lateral and lower view of S1 element, sample PZ019top. $\bullet \mathrm{K}$ - postero-lateral and lower view of S0 element, sample PZ019top. $\bullet \mathrm{L}$ - inner lateral and lower view of S2 element, sample PZ019top. $\bullet \mathrm{M}$ - lateral and lower view of short paucidantate P1 element with large basal lobes, sample PZ019top. $\bullet \mathrm{N}$ - lateral view of P1 element, sample PZ022. • O - lateral and lower-lateral view of P1 element, sample PZ019top. -P - lateral view of P1 element, sample PZ019top. • Q - lateral view of P1 element, sample PZ019top. $\bullet$ X - lateral view of P1 element, sample PZ022. -Y - lateral view of P1 element, sample PZ019top. •Z - lateral view of P1 element, sample PZ022. • ZZ - lateral view of P1 element, sample PZ022. All specimens are deposited in the collections of Ladislav Slavík at the Institute of Geology AS CR, v.v.i. and Peter Carls at the Technische Universität Braunschweig. All figures are the same scale (scale bar equals $500 \mu \mathrm{m}$ ).

Gotland that is regarded older than the snajdri Interval Zone. In Sardinia (Corriga et al. 2009), the LAD of Ped. latialatus is approximated to the FAD of "Oz." snajdri. As listed above, there exist more indices pointing to the earlier entry of Ped. latialatus. In spite of its scarcity the range of Ped. latialatus also in the Cellon section is relatively long. In the Požáry section, the most representative specimens were obtained from the last sample of its occurrence well above the entry of "Oz." crispa (see Fig. 3R, S). 


\section{The parasnajdri Biozone}

The beginning of the zone is defined herein by the entry of "Ozarkodina" parasnajdri Viira \& Aldridge, 1998 and its end by the entry of "Oz." crispa (Walliser, 1964). The range of this morphology is comparatively long and its entry is younger than that of "Oz." snajdri but older than that of "Oz." crispa. In Bohemia, the overlap with "Oz." crispa is long. Elsewhere, there are other age relations: The taxon parasnajdri was reported by Viira (1999, text-fig. 3) from the Kuressaare and early Kaugatuma Regional Stages. There it co-occurs with Zieglerodina? baccata, which locally brackets it, and it survives or even entirely ranges above "Oz." crispa. According to Miller \& Aldridge (1997), Z.? baccata occurs throughout the Upper Whitcliffe Formation and it roughly corresponds to the range of "Oz." snajdri in Gotland ( $c f$. correlation in Jeppsson \& Aldridge 2000 and Jeppsson et al. 2006). Apparently, the upper range of " $O z$." parasnajdri recorded in the Eastern Baltica is longer than that in Bohemia. The snajdri Interval Zone is not used in the Prague Synform because the conodont record allows a more detailed subdivision. The snajdri Interval Zone, according to Corradini \& Serpagli (1999), is limited below by the last occurrence of Ped. latialatus and above by the first occurrence of $O z$. crispa. But as seen in Bohemia and mentioned above, Ped. latialatus brackets the range of "Oz." snajdri. Nevertheless, for correlations the taxon snajdri offers a distinct morphology that can serve as a biostratigraphic tool. The entry of the early appearing taxon parasnajdri is a morphological step towards the subsequent origin of "Oz." crispa, but this step does not yet reach "Oz." crispa. There is a parallel taxon herein informally addressed as "Oz." snajdri-crispa ( $c f$. Fig. 4O). The formalistic application of a snajdri Interval Zone in a zonation scale would be useless because there is no space for it (see the overlap of LAD of Ped. latialatus and of the FAD of "Oz." crispa in Fig. 2).

\section{The crispa Biozone}

The crispa Zone starts with the entry of "Oz." crispa in bed No. 84, $1 \mathrm{~m}$ below the end of the Kopanina Formation in the late Ludfordian. In the Prague Synform, no specimens of crispa straddle the graptolite-defined Ludlow-Přídolí boundary. According to the revision of conodont data (by Schönlaub in Kříž et al., 1986, p. 336 and in this paper), the taxon crispa ends usually closely below or just below the base of the Prrídolí (i.e. below the entry of Pseudomonoclimacis parultimus). Its range up to the very top of the Ludfordian is not certain because the sea-level fluctuation just below the base of the Přídolí caused gaps in several sections (e.g., Kosov Quarry). The absolute completeness of the sedimentary record at the very end of the Ludfordian in the Požáry and Mušlovka sections cannot be proven, but it seems that the extinction of "Oz." crispa can be traced just below the Ludlow-Př́idolí limit. Also the last occurrence of "Oz." crispa just below the interbed with Ps. parultimus in the Cellon section confirms this concept (Carnic Alps, Schönlaub in Kříž et al. 1986, p. 336). The LAD of "Oz." crispa is also used as a marker for the end of the Ludlow (e.g., Sardinia, Corriga et al. 2009).

Jeppsson \& Aldridge (2000) introduced the Klev Event that starts at or closely below the extinction of "Oz." crispa and ends in the earliest Přídolí. According to data from the Prague Synform ( $c f$. Kříž et al. 1986), the correlation with the base of $P$. fragmentalis graptolite Zone cannot be accurate because its entry in the Prague Synform is not exactly known. The effect of the local Klev Event from Gotland cannot be reproduced in Bohemia, because there is practically no sedimentary record available for it in the topmost Ludfordian (i.e. above the disappearance of "Oz." crispa). The correlation of the upper limit of the Klev Event is also uncertain and the frequent records of changes in various faunal groups are provoked by the discussion concerning the Ludlow-Přídolí boundary.

Thus, the upper limit of the crispa Zone is formally independent of the base of the Přídolí as that is defined by the entry of the graptolite Ps. parultimus. As a Bohemian conodont marker near this base Zieglerodina zellmeri Carls et al., 2007 may serve; it enters in the basal Přídolí bed (Carls et al. 2007). This taxon has been recently reported also from the Carnic Alps and Sardinia to enter close to the base of the Přídolí (Corradini \& Corriga 2012).

\section{Conclusions}

The post-Lau Event diversity increase of conodont faunas in the Prague Synform (Barrandian area in Bohemia) starts with the appearance of slender spathognathodontid taxa in which the oldest is probably Parazieglerodina plodowskii Carls et al., 2005. Our review of the Bohemian conodont faunal succession exposes its potential for the characterization of a succession of seven time intervals from the Ludfordian siluricus Zone to the zellmeri range in the Přídolí.

Figure 7. A, D, G, H, I, K, M, N, P, Q - Ozarkodina ex gr. typica Branson \& Mehl, 1933. • A - lateral and lower view of P1 element, sample PZ019top. - D - lateral view of P1 element, sample PZ020a. $\bullet \mathrm{G}$ - lateral and lower view of P2 element, sample PZ019top. $\bullet \mathrm{H}-$ lateral and upper view of P1 element, sample PZ020a. • I - lateral and lower view of P2 element, sample PZ019top. • K - lateral view of P1 element, sample PZ020a. $\bullet$ M - lateral and lower 


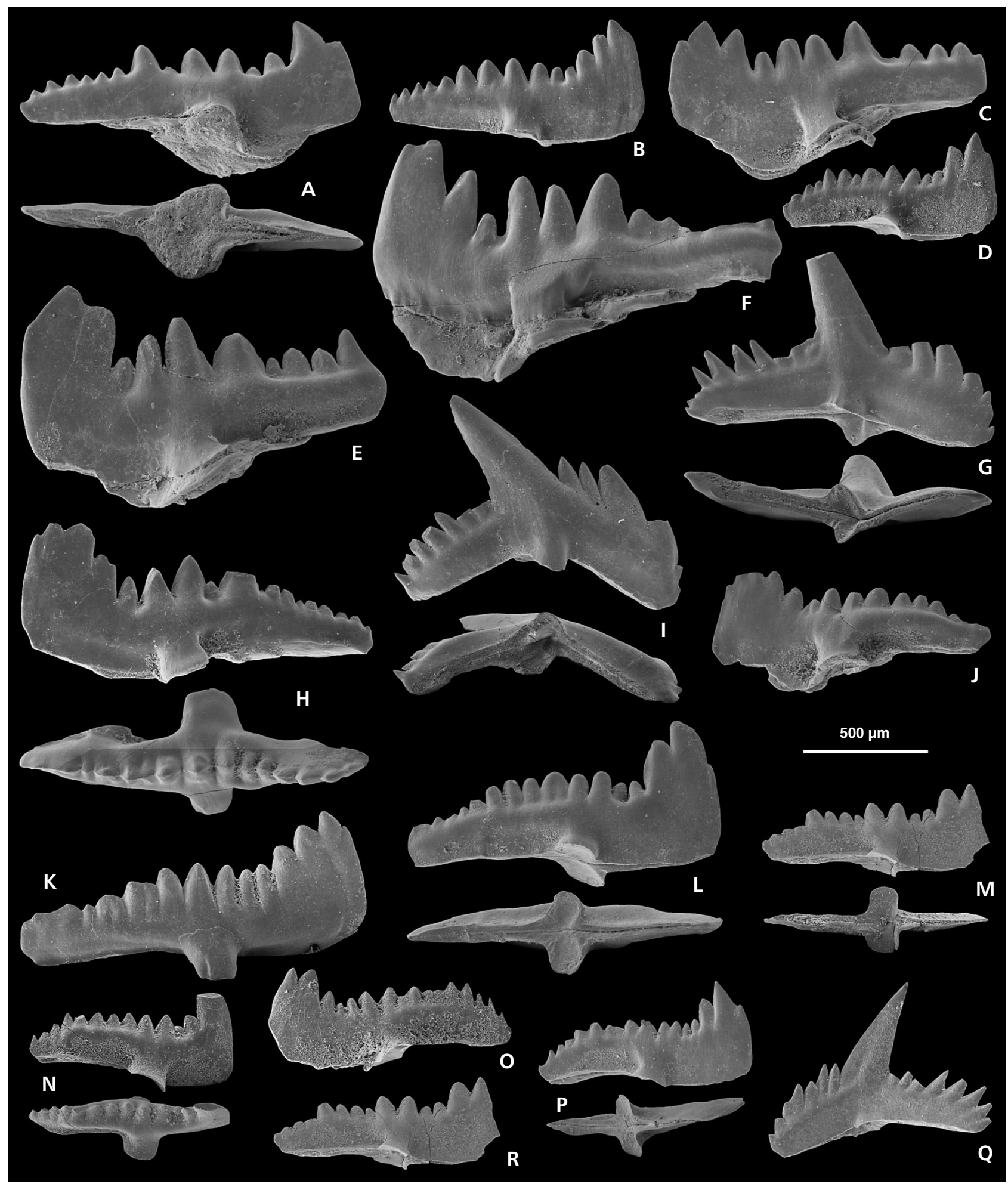

view of P1 element, sample PZ020a. $\bullet$ N - lateral and upper view of P1 element, sample PZ020a. $\bullet$ P lateral and lower view of P1 element, sample PZ020a. • Q - lateral view of P2 element, sample PZ019top. • B - Ozarkodina cornidentata (Viira, 1983), lateral view of P1 element, sample PZ019top. - C, E, F - Ozarkodina cf. cornidentata (Viira, 1983). • C - lateral view of P1 element, sample PZ019top. • E - lateral view of P1 element, sample PZ019top. • F - lateral view of P1 element, sample PZ019top. • J, L, R - Ozarkodina cf. ambigua (Viira, 1983). $\mathbf{J}$ - lateral view of P1 element, sample PZ020a. $\bullet \mathrm{L}$ - lateral and lower view of P1 element, sample PZ020a. $\bullet \mathrm{R}$ - lateral view of P1 element, sample PZ020a. O - Ozarkodina ambigua (Viira, 1983), lateral view of P1 element, sample PZ020a. All specimens are deposited in the collections of Ladislav Slavík at the Institute of Geology AS CR, v.v.i. and Peter Carls at the Technische Universität Braunschweig. All figures are the same scale (scale bar equals $500 \mu \mathrm{m}$ ). 
The conodont faunas increased in diversity and abundance enable a refined conodont subdivision of the post-Lau Event interval in the Ludfordian. It includes the plodowskii, latialatus, parasnajdri and crispa biozones. The presented regional conodont zonation for the post-siluricus interval in the late Ludfordian of Bohemia is not intended as a global standard, because for that purpose it would have to be carefuly tested in other regions in order to fulfil the general characteristics for global biozonation ( $c f$. Corradini $\&$ Barrick 2009). The data from Bohemia show that the use of a snajdri Interval Zone is useless, because its index enters quite shortly after Ped. latialatus. The use of snajdri interval as a basis for the definition of the Lu2 Stage Slice (i.e. approximately middle Ludfordian, Cramer et al. 2011) should be avoided. In the present paper the use of a distinct morphological change in the snajdri-crispa group is suggested that enables the refinement of the biozonal subdivision. The sum of plodowskii, latialatus and parasnajdri zones roughly corresponds to the time of a moderate sea-level rise in the upper part of the Pseudomonoclimacis latilobus-Slovinograptus balticus graptolite Zone (cf. Manda \& Kř́iž 2006, Manda et al. 2012). The "Icriodontid" Zone of Jeppsson (2005) delimited on Gotland cannot be correlated with any of the regional zones in the Prague Synform because of extreme scarcity of icriodontids on Gotland. The recognition of the Klev Event near the beginning of the Přídolí is not possible in Bohemia, probably due to the more complete ranges of "Oz." crispa and its associates in Bohemia, which were not affected by this rather local event. A good correlation with Eastern Baltica is enabled by the sharp change from Ozarkodina cornidentata (Viira, 1983) to Ozarkodina ambigua (Viira, 1983) within the Ozarkodina typica lineage. It may represent stratigraphically important level approximately amid the crispa Zone. According to Viira (1999), Oz. cornidentata is limited to the Paadla Stage, whereas its younger descendant, Oz. ambigua, occurrs only in the Kuressaare Stage. The morphological variability in $\mathrm{Oz}$. ex gr. typica is, however, relatively high and the stratigraphic value of this change still has to be tested in more regions.

\section{Acknowledgments}

This paper was developed with the support of the Czech Science Foundation (project No. 205/09/0703 (Late Silurian integrated stratigraphy...) and of the Institute of Geology AS CR, v.v.i. (Institutional project: AV0Z30130516). The authors highly appreciate reviews by Carlo Corradini and James E. Barrick that have helped to improve the manuscript considerably. We thank P. Lisý who helped with the plate preparation and sample processing, J. Bressler for heavy liquid separation, Z. Korbelová for SEM images. Our thanks are also expressed to Hans Peter Schönlaub and Rouben Surenian from the Geologische Bundesanstalt Wien for access to the conodont collection there for study. Jiři Kř́žz, Petr Štorch and Štěpán Manda are acknowledged for valuable discussions about the late Silurian in Bohemia, graptolite stratigraphy and local sedimentology. This paper is a contribution to IGCP projects No. 591 - The Early to Middle Paleozoic Revolution and No. 596 - Climate change and biodiversity patterns in the Mid-Paleozoic.

\section{References}

Barrick, J.E, Kleffner, M.A., Gibson, M.A, Peavey, F.N. \& KARLSSON, H.R. 2010. The mid-Ludfordian Lau Event and Carbon Isotope Excursion (Ludlow, Silurian) in southern Laurentia - Preliminary Results. Bollettino della Società Paleontologica Italiana 49(1), 13-33.

Bischoff, G.C.O. \& Sannemann, D. 1958. Unterdevonische Conodonten aus dem Frankenwald. Notizblatt des Hessischen Landesamtes für Bodenforschung 86, 87-110.

Branson, E.B. \& Mehl, M.G. 1933. Conodont Studies. University of Missouri Studies 8(1-4), 1-343.

CARLS, P. \& Slavík, L. 2005. Upgrading of magnetic susceptibility of conodont sample residues before magnetic separation. Lethaia 38, 171-172. DOI 10.1080/00241160510013213

Carls, P., Slavík, L. \& Valenzuela-Ríos, J.I. 2005. A new Ludlow (late Silurian) Spathognathodontidae (Conodonta) from Bohemia with incipient alternating denticulation. Neues Jahrbuch für Geologie und Paläontologie, Monatshefte 9, 547-565.

Carls, P., Slavík, L. \& Valenzuela-Ríos, J.I. 2007. Revision of conodont biostratigraphy across the Silurian-Devonian boundary. Bulletin of Geosciences 82(2), 145-164.

DOI 10.3140/bull.geosci.2007.02.145

COOPER, B.J. 1974. New Forms of Belodella (Conodonta) from the Silurian of Australia. Journal of Paleontology 48, 1120-1125.

Corradini, C. 2007. The conodont genus Pseudooneotodus Drygnat from the Silurian and Lower Devonian of Sardinia and the Carnic Alps (Italy). Bollettino della Società Paleontologica Italiana 46(2-3), 139-148.

CorRadini, C. 2009. Looking for a late Silurian Standard Conodont Zonation: still a long way to go, 273-274. In CORRIGA, M.G. \& PIRAS, S. (eds) Time and Life in the Silurian: a multidisciplinary approach. Abstracts. Rendiconti della Società Paleontologica Italiana 3(3).

Corradini, C. \& Barrick, J.E. 2009. The Standard Zonation concept - examples from the Silurian conodont zonation, 22-23. In Suttner, T.J., Hubmann, B. \& Piller, W.E. (eds) Paleozoic Seas Symposium. Berichte des Institutes für Erdwissenschaften Karl-Franzens-Universität Graz 14.

Corradini, C. \& Corriga, M.G. 2010. Silurian and lowermost Devonian conodonts from the Passo Volaia area (Carnic Alps, Italy). Bollettino della Società Paleontologica Italiana 49(3), 237-253.

Corradini, C. \& Corriga, M.G. 2012. A Přídolí-Lochkovian conodont zonation in Sardinia and the Carnic Alps: implications for a global zonation scheme. Bulletin of Geosciences 87(4), 635-650.

DOI 10.3140/bull.geosci.1304 
Corradini, C. \& Serpagli, E. 1999. A Silurian conodont biozonation from late Llandowery to end Pridoli in Sardinia (Italy), 255-273. In Serpagli, E. (ed.) Studies on Conodonts. Proceedings of the Seventh European Conodont Symposium. Bollettino della Società Paleontologica Italiana 37.

Corriga, M.G. \& CoRradini, C. 2009. Upper Silurian and Lower Devonian conodonts from the Monte Cocco II Section (Carnic Alps, Italy). Bulletin of Geosciences 84(1), 155-168. DOI 10.3140/bull.geosci.1112

Corriga, M.G., Corradini, C. \& Ferretti, A. 2009. Silurian conodonts from Sardinia: an overview, 95-107. In CoRRADINI, C., Ferretti, A. \& Štorch, P. (eds) The Silurian of Sardinia. Rendiconti della Società Paleontologica Italiana 3(1).

Cramer, B.D., Brett, C.E., Melchin, M.J., Männik, P., KlefFNer, M.A., McLaughlin, P.I., Loydell, D.K., MunNeCKe, A., Jeppsson, L., Corradini, C., Brunton, F.R. \& Saltzman, M.R. 2011. Revised correlation of Silurian Provincial Series of North America with global and regional chronostratigraphic units and $\delta^{13} \mathrm{C}$ carb chemostratigraphy. Lethaia 44 , 185-202.

DOI 10.1111/j.1502-3931.2010.00234.x

Drygant, D.M. 1974. Prostye konodonty silura i nizov devona Volyno-Podol'ya [Simple conodonts from the Silurian and lowermost Devonian of Volyno-Podolia]. Palaeontologicheskii Sbornik 10, 64-70.

HoRnÝ, R. 1955. Studie o vrstvách budňanských v západní části Barrandienu. Sborník Ústředního ústavu geologického, Oddíl geologický 21, 315-447.

Chlupáč, I., Kříž, J. \& Schönlaub, H.P. 1980. Field Trip E. Silurian and Devonian conodonts of the Barrandian, 147-180. In Schönlaub, H.P. (ed.) Second European Conodont Symposium ECOS II. Guidebook - Abstracts. Abhandlungen der Geologischen Bundesanstalt 35.

JepPsson, L. 1998. Silurian oceanic events. Summary of general characteristics, 239-257. In LANDing, E. \& Johnson, M.E. (eds) Silurian cycles: Linkages of dynamic stratigraphy with atmospheric, oceanic and tectonic changes. New York State Museum Bulletin 491.

Jeppsson, L. 2005. Conodont-based revisions of the Late Ludfordian on Gotland, Sweden. GFF 127, 273-282.

DOI 10.1080/11035890501274273

JepPSSon, L. \& AldRidge, R.J. 2000. Ludlow (late Silurian) oceanic episodes and events. Journal of the Geological Society London 157, 1137-1148. DOI 10.1144/jgs.157.6.1137

Jeppsson, L., Eriksson, M.E. \& CALner, M. 2006. A latest Llandovery to latest Ludlow high-resolution biostratigraphy based on the Silurian of Gotland - a summary. GFF 128, 109-114.

\section{DOI 10.1080/11035890601282109}

KLAPPER, G. \& PhiLIP, G.M. 1971. Devonian conodont apparatuses and their vicarious skeletal elements. Lethaia 4, 429-452. DOI 10.1111/j.1502-3931.1971.tb01865.x

KNİ̌̌EK, M., Melichar, R. \& JANEČKA, J. 2010. Stratigraphic separation diagrams as a tool for determining fault geometry in a folded and thrusted region: an example from the Barrandian region, Czech Republic. Geological Journal 45, 536-543. DOI 10.1002/gj.1206
KŘiž, J. 1998. Recurrent Silurian-Lowest Devonian cephalopod limestones of Gondwanan Europe and Perunica, 183-198. In Landing, E. \& Johnson, M.E. (eds) Silurian Cycles: Linkages of Dynamic Stratigraphy with Atmosphaeric, Oceanic, and Tectonic Changes (James Hall Centennial Volume). New York State Museum Bulletin 491.

KŘiž, J. 1991. The Silurian of the Prague Basin (Bohemia) - tectonic, eustatic and volcanic controls on facies and faunal development, 179-203. In BAsset, M.G., LANE, P.D. \& EDwards, D. (eds) The Murchison Symposium. Proceedings of an international conference on The Silurian System. Special Papers in Palaeontology 44.

KŘiž, J. 1992. Silurian field excursions: Prague Basin (Barrandian) Bohemia. National Museum of Wales, Geological Series 13, 1-111.

KŘiž, J., JAeger, H., PARIs, F. \& SchÖNlaub, H.P. 1986. Př́ídolí the fourth subdivision of the Silurian. Jahrbuch der Geologischen Bundesanstalt 129, 291-360.

KŘiž, J., JAEGER, H. \& SchöNLAUb, H.P. 1981. The Přídolí Series as the fourth series of the Silurian System. A submission to the Subcommission on Silurian Stratigraphy, International Commission on Stratigraphy, Subcommission on Silurian Stratigraphy, May 1981, 1-41.

Lehnert, O., Frýda, J., Buggisch, W., Munnecke, A., NütZel, A., KŘılž, J. \& MANDA, Š. 2007. $\delta^{13}$ C records across the late Silurian Lau Event: new data from middle paleolatitudes of northern peri-Gondwana. Palaeogeography, Palaeoclimatology, Palaeoecology 245, 227-244.

DOI 10.1016/j.palaeo.2006.02.022

MANDA, S̆. 2008. Palaeoecology and palaeogeographic relations of the Silurian phragmoceratids (Nautiloidea, Cephalopoda) of the Prague Basin (Bohemia). Bulletin of Geosciences 83(1), 39-62.

DOI 10.3140/bull.geosci.2008.01.039

MANDA, Š. \& FRÝDA, J. 2010. Silurian-Devonian boundary events and their influence on cephalopod evolution: evolutionary significance of cephalopod egg size during mass extinctions. Bulletin of Geosciences 85(3), 513-540.

DOI 10.3140/bull.geosci.1174

MANDA, Š. \& Kř́iž, J. 2006. Environmental and biotic changes of the subtropical isolated carbonate platforms during Kozlowskii and Lau events (Prague Basin, Silurian, Ludlow). GFF 128, 161-168.

DOI 10.1080/11035890601282161

Manda, Š., ŠTorch, P., Slaví́, L., FrÝda, J., KŘíž, J. \& TASÁRYOVÁ, Z. 2012. Graptolite, conodont and sedimentary record through the late Ludlow Kozlowskii Event (Silurian) in shale-limestone succession of Bohemia. Geological Magazine 149(3), 507-531.

\section{DOI $10.1017 /$ S0016756811000847}

Mehrtens, C.J. \& BarnetT, S.G. 1976. Conodont subspecies from the Upper Silurian-Lower Devonian of Czechoslovakia. Micropaleontology 22, 491-500. DOI $10.2307 / 1485177$

Melichar, R. 2004. Tectonics of the Prague Synform: a hundred years of scientific discussion. Krystalinikum 30, $167-187$.

Miller, C.G. \& AldRIDGe, R.J. 1997. Ozarkodina remscheidensis plexus conodonts from the upper Ludlow (Silurian) of 
the Welsh Borderland and Wales. Journal of Micropalaeontology 16, 41-49.

DOI 10.1144/jm.16.1.41

Murphy, M.A., Valenzuela-Ríos, J.I. \& Carls, P. 2004. On Classification of Pridoli (Silurian)-Lochkovian (Devonian) Spathognathodontidae (Conodonts). University of California, Riverside Campus Museum Contribution 6, 1-25.

Nowlan, G.S. 1995. Left Hand Column for Correlation Charts. Silurian Times 3, 7-8.

PhiLIP, G.M. 1965. Lower Devonian conodonts from the Tyers area, Gippsland, Victoria. Proceedings of the Royal Society of Victoria 79, 95-117.

ReXroad, C.B. \& Craig, W.W. 1971. Restudy of conodonts from the Bainbridge Formation (Silurian) at Lithium, Missouri. Journal of Paleontology 45, 684-703.

Rhodes, F.H.T. 1953. Some British Lower Palaeozoic conodont faunas. Philosophical Transactions of the Royal Society of London, Series B: Biological Sciences 237, 261-328. DOI 10.1098/rstb.1953.0005

SIMPSON, A. 1995. Silurian conodont biostratigraphy in Australia: A review and critique. Courier Forschungsinstitut Senckenberg 182, 325-345.

Slavík, L., Carls, P., Hladil, J. \& Koptíková, L. in press. Subdivision of the Lochkovian Stage based on conodont faunas from the stratotype area (Prague Synform, Czech Republic). Geological Journal.

DOI $10.1002 / \mathrm{gj} .2420$
Slavík, L., KŘiž, J. \& CARLs, P. 2010. Reflection of the midLudfordian Lau Event in conodont faunas of Bohemia. Bulletin of Geosciences 85(3), 395-414.

DOI 10.3140/bull.geosci.1204

TonarovÁ, P., Eriksson, M.E. \& Hints, O. 2012. A jawed polychaete fauna from the late Ludlow Kozlowskii event interval in the Prague Basin (Czech Republic). Bulletin of Geosciences 87(4), 713-732.

DOI 10.3140/bull.geosci.1317

VIIRA, V. 1983. Spatognatodusy (konodonty) verchnevo silura Estonii, 41-71. In KlaAmann, E. (ed.) Paleontologia drevnego paleozoya Pribaltiki $i$ Podolii. Akademiia nauk Estonskoy SSR, Institut geologii, Tallinn.

VIIRA, V. 1999. Late Silurian conodont biostratigraphy in the northern East Baltic, 299-310. In Serpagli, E. (ed.) Studies on Conodonts. Proceedings of the Seventh European Conodont Symposium. Bollettino della Società Paleontologica Italiana 37.

VIIRA, V. \& ALDRIDGE, R.J. 1998. Upper Wenlock to Lower Přídolí (Silurian) conodont biostratigraphy of Saaremaa, Estonia, and a correlation with Britain. Journal of Micropalaeontology 17, 33-50.

DOI 10.1144/jm.17.1.33

WALLISER, O.H. 1964. Conodonten des Silurs. Abhandlungen des Hessischen Landesamtes für Bodenforschung 41, 1-106.

WALLISER, O.H. \& WANG, C.Y. 1989. Upper Silurian stratigraphy and conodonts from the Qujing District, East Yunnan, China. Courier Forschungsinstitut Senckenberg 110, 111-121. 